\title{
Marta Krzemińska
}

Uniwersytet Kardynała Stefana Wyszyńskiego w Warszawie

ORCID: 0000-0002-9515-3530

DOI: https://doi.org/10.21697/ucs.2020.26.2.06

\section{Sprawozdanie ze spotkania z cyklu Economic Lunchtime Seminars pt. Global impact of the coronavirus epidemic}

17 grudnia 2020 r. o godz. 15:00 rozpoczęło się kolejne spotkanie z cyklu Economic Lunchtime Seminars zatytułowane Global impact of the coronavirus epidemic. Moderatorem spotkania był dr inż. Piotr Komorowski z Katedry Finansów Wydziału Społeczno-Ekonomicznego UKSW, zaś prelegentem gościnnym - amerykański prawnik i ekonomista, profesor Karl William Viehe z George Washington University i New York University. Ze względu na reżim sanitarny związany z panującą pandemią koronawirusa spotkanie odbyło się w trybie zdalnym, za pośrednictwem platformy Zoom.

Moderator powitał uczestników, przedstawił gościa i wprowadził w tematykę prelekcji. Wspomniał o spotkaniu z profesorem K.W. Viehe, do którego doszło na uczelni w 2019 r. Następnie odniósł się do trudnej sytuacji epidemicznej, w której aktualnie się znajdujemy. Po tym krótkim wstępie oddał głos gościowi.

Profesor K.W. Viehe powitał słuchaczy i wyraził żal, że spotkanie nie może odbyć się w formie tradycyjnej, a jedynie za pośrednictwem platformy komunikacyjnej. Zaczął od porównania do obecnie trwającej pandemii koronawirusa epidemii grypy hiszpanki, która opanowała Stany Zjednoczone w 1918 r. i trwała przez około półtora roku. Przedstawił dane, omawiając, jak kształtował się wówczas i jak kształtuje się obecnie wskaźnik reprodukcji wirusa, czyli parametr informujący o tym, ile osób zaraża jeden zainfekowany pacjent. W 1918 r. wskaźnik ten oscylował wokół 1,8, podczas gdy w przypadku SARS-CoV-2 jego wartość wynosi 2-2,5. Przedstawiając dane o śmiertelności na SARS-CoV-2 w Stanach Zjednoczonych, profesor wyraził duże zaniepokojenie. Zwrócił uwagę na to, że na początku pandemii obywatele zlekceważyli rygor sanitarny, co przyczyniło się do przerażająco szybkiego skoku zakażeń w kolejnych miesiącach.

W opinii profesora K.W. Viehe do pogorszenia sytuacji przyczyniło się w dużym stopniu nieodpowiedzialne zachowanie ludzi, którzy, zmęczeni reżimem, przestali go przestrzegać, zdejmując maski, nie zachowując odpowiedniego dystansu etc. Ponadto zwrócił uwagę, że liczba zachorowań rozkłada się różnie w zależności od wielkości populacji danego stanu. Każdy z trzech największych stanów, tj. Kalifornię, Teksas i Florydę, zamieszkuje około $20 \mathrm{mln}$ bądź więcej ludzi. W tych największych pod względem liczby mieszkańców stanach lekceważenie restrykcji przez ludzi chcących wrócić do „normalnego" życia było najbardziej brzemienne w skutki. Inaczej wygląda natomiast sytuacja w środkowych stanach (takich jak Iowa i Oklahoma), oraz w stanach północnych (np. Minnesota), które mają mniejszą populację. W tych regionach skala problemów z wirusem jest mniejsza.

Według prelegenta czynnikiem wpływającym na to, w jakim stopniu przestrzegany jest reżim sanitarny, są preferencje polityczne ludności i związany z tym podział polityczny na Partię Republikańską i Partię Demokratyczną. Podziały polityczne w społeczeństwie amerykańskim są tak silne, że stany, w których dominuje partia Demokratów, są mniej skłonne do przestrzegania obostrzeń, jako że obostrzenia te są nakładane przez prezydenta Donalda Trumpa, który jest republikaninem.

W dalszej części prelekcji profesor K.W. Viehe przeszedł do zagadnień globalnych. Omówił krótko sytuację w Rosji, gdzie w okolicach Moskwy i w zachodniej części kraju reżim sanitarny przestrzegany jest w o wiele większym stopniu niż w pozostałych częściach tego ogromnego kraju. We Francji obostrzenia nie są przestrzegane zwłaszcza przez niechętnie asymilujących się imigrantów. Doktor P. Komorowski dodał wówczas, iż kwestia imigrantów dotyczy praktycznie całej Europy, przede wszystkim zaś Niemiec, Włoch, Wielkiej Brytanii, Norwegii i Szwecji. 
Doktor P. Komorowski zwrócił uwagę, że Stany Zjednoczone są krajem o najwyższym PKB oraz że sytuacja gospodarcza tego kraju istotnie wpływa na cały świat. Przytoczył bardzo ciekawą teorię „Dollar Milkshake” Brenta Johnsona. Krótko mówiąc, według tej teorii światowa ekonomia zależy od przepływów dolara.

Profesor K.W. Viehe tłumaczył, że w czasie pandemii Stany Zjednoczone wprowadzily na rynek ogromne sumy pieniędzy, około 20-30 trylionów dolarów. Zapowiedziano przy tym „pompowanie” pieniędzy do czasu ustąpienia koronakryzysu. Według prelegenta nowy prezydent, przedstawiciel demokratów - Joe Biden, nie będzie mógł wpłynąć na politykę monetarną, gdyż Systemem Rezerwy Federalnej zarządza autonomicznie działający Federalny Komitet do spraw Operacji Otwartego Rynku (Federal Open Market Committee FOMC). W ocenie możliwości pompowania pieniądza w gospodarkę, w opinii profesora, ważne jest to, że w roku, w którym pojawił się koronawirus, inflacja w Stanach Zjednoczonych była zaskakująco niska. Prelegent zauważył, że podczas niedawnych krachów ekonomicznych wartość dolara spadła tylko nieznacznie. W warunkach pandemii bardzo trudno jest przewidzieć zmiany wartości waluty, na którą to wartość niebagatelny wpływ ma również sytuacja polityczna. Zdaniem profesora największym wyzwaniem dla nowego prezydenta będzie stabilizacja ekonomiczna.

Jak zauważył doktor P. Komorowski, problem stabilizacji ekonomicznej nie dotyczy jedynie Stanów Zjednoczonych, lecz całego „zachodniego” świata - w przeciwieństwie do Azji, gdzie sytuacja ekonomiczna jest dość dobra. Duży wpływ ma na to m.in. przeniesienie do krajów azjatyckich ogromnej części światowej produkcji. Doktor P. Komorowski jako jeden z czynników niesprzyjających zachodniej części świata wskazał niski przyrost naturalny. Wyraził opinię, że największym problemem zarówno Europy, jak i Stanów Zjednoczonych będzie powrót do kondycji gospodarczej sprzed pandemii.

Według profesora K.W. Viehe jednym z najistotniejszych wydarzeń, które należy uwzględnić przy prognozowaniu sytuacji gospodarczej Stanów Zjednoczonych, są aktualnie przeprowadzane wybory. Oprócz prezydenta, Amerykanie wybierają również członków Senatu. Nadal toczy się walka o dwa miejsca w ramach wyborów uzupełniających w Georgii. Wyniki tej walki przesądzą o tym, czy w Senacie przewagę przejmie partia republikanów, czy partia demokratów. Prelegent wyraził obawę, że w wyniku niekorzystnej sytuacji społeczno-ekonomicznej mogłoby dojść do deprecjacji dolara. Podkreślił, że najbliższe 5-6 miesięcy to okres istotnych wydarzeń politycznych w Stanach Zjednoczonych. Dopiero po tych wydarzeniach możliwa będzie predykcja polityki gospodarczej.

Porównując rynki największych graczy na arenie światowej, profesor zwrócił uwagę na fakt, iż - mimo swojej wielkości terytorialnej - Rosja nie ma aż tak dużego znaczenia pod względem gospodarczym. Wynika to między innymi z małego zaludnienia olbrzymiego terytorium. W związku z tym nie jest ona atrakcyjnym partnerem biznesowym. Z kolei Chiny są już potęgą ekonomiczną. Profesor zwrócił uwagę również na to, że na rynku zaczynają pojawiać się potężne firmy z Arabii Saudyjskiej. Jego zdaniem dla Stanów Zjednoczonych najważniejszymi graczami aktualnie są właśnie Chiny, Arabia Saudyjska i Rosja. Według profesora Japonia nie jest już tak atrakcyjnym rynkiem ze względu na brak wzrostu. Podobnie Unia Europejska, która ma wprawdzie wielki potencjał, jednak też nie jest wystarczająco progresywna.

Doktor P. Komorowski zauważył, że potęga gospodarcza Chin powstała głównie dzięki produkcji „plastiku”, rozumianej jako produkcja tanich wyrobów z tworzyw sztucznych, przeznaczonych na eksport, wytwarzanych na bezprecedensową skalę, zaspokajających popyt w wymiarze globalnym. Już w latach 90 . XX w. w Chinach produkowano ogromne ilości wyrobów plastikowych, które zalewały rynek światowy. Mimo że początkowo prześmiewczo mówiono, iż z masową produkcją traci się na jakości, aktualnie Chiny są potęgą przemysłu technologicznego. Doktor podkreślił, że Chiny stosunkowo dobrze radzą sobie z koronawirusem. Mimo wielkiej liczby zakażeń na początku pandemii obecnie w całych Chinach pojawia się jedynie około dziesięciu przypadków zakażenia dziennie. Warto jednak pamiętać, że dane rządowe mogą nie odpowiadać rzeczywistej sytuacji w tym kraju.

W dalszej części spotkania profesor K.W. Viehe omówił aktualne obostrzenia oraz wsparcie finansowe działalności gospodarczej w Stanach Zjednoczonych, informując, że zamknięto przeważającą część sektora usług, w tym restauracje. Większość decyzji o lock-downie podejmuje się jednak nie na poziomie federalnym, lecz stanowym. To samo dotyczy wsparcia finansowego - pieniądze federalne przekazywane są do 
poszczególnych stanów, gdzie władze stanowe decydują o ich przeznaczeniu. Choć wiele firm dostaje wsparcie, nadal wiele biznesów upada.

Prelekcja spotkała się z ogromnym zainteresowaniem ze strony studentów. Liczba zainteresowanych przekroczyła oczekiwania. Wynoszący 100 osób limit platformy Zoom został całkowicie wypełniony. Uczestnicy aktywnie brali udział w dyskusji, zadając rozmaite pytania, na które prelegent chętnie odpowiadał.

Po części dyskusyjnej nastąpiły podziękowania i pożegnanie uczestników spotkania. Na koniec organizatorzy zapowiedzieli kolejne prelekcje z cyklu Economic Lunchtime Seminars - najbliższą zaplanowano już w styczniu 2021 r.

Dziękuje serdecznie Panu Doktorowi Adrianowi Sadtowskiemu za wsparcie i zrozumienie.

Marta Krzeminska 